\title{
Therapeutic Walks in Virtual Nature
}

\author{
Benny Rigaux-Bricmont \\ FSA ULAVAL, Québec, Canada \\ Email: benny.rigaux-bricmont.1@ulaval.ca
}

How to cite this paper: Rigaux-Bricmont, B. (2018) Therapeutic Walks in Virtual Nature. Advances in Aging Research, 7, 119-131. https://doi.org/10.4236/aar.2018.76010

Received: October 5, 2018

Accepted: November 11, 2018

Published: November 14, 2018

Copyright (C 2018 by author and Scientific Research Publishing Inc. This work is licensed under the Creative Commons Attribution International License (CC BY 4.0).

http://creativecommons.org/licenses/by/4.0/

\begin{abstract}
Can the benefits of nature walks for psychological well-being and cognitive ability be replicated in a purely virtual environment? The private island of Natmoud was built in the virtual world of Second Life $(S L)$ to see whether immersion in such an environment is possibly therapeutic (see Appendix). This exploratory study is based on a small convenience sample of SL residents who were invited by the author's avatar to visit Natmoud island. The subjects were asked to comment in writing on their experience while there. Reading and analyzing these comments with TROPES semantic software allows us to identify the main factors contributing to a relaxing and comforting atmosphere with an analysis of word associations. The implicit hypothesis that a virtual representation of nature can be soothing is confirmed. We also find that wildlife-which is abundant on the island ${ }^{*}$-appears to be the main feature that catches the attention of walkers. Given that these verbatim transcripts from a small convenience sample reflect, with one exception, the emotions felt by women, the results cannot really be generalized. In the analyses, the anonymity of the avatars is preserved by using initials, even though in all the cases the participants consented to the reproduction of the emotions they expressed.
\end{abstract}

\section{Keywords}

Virtual Environment, Second Life, Psychological Health

\section{Introduction}

The research program, of which the study presented here is the first milestone, made the front page of a Montreal newspaper (Le Devoir) a few years ago [1]. Overall, the program aims to examine whether immersion through avatars in virtual worlds such as Second Life or Sansar (developed by Linden Lab) [2] or High Fidelity [3] on the part of stressed individuals who are in psychological distress or possibly disabled [4] [5], can improve the quality of their real life [6]. In particular, we have in mind escaping loneliness and alleviating physical or 
mental distress through various virtual activities such as co-production within the "metaverse" or participation in artistic activities (visits to virtual museums and art galleries, attendance at streamed live concerts, virtual tourism at famous sites, etc.) or recreational activities (role playing, underwater swimming, sailing, etc.). Since the benefits of nature walks for psychological well-being and cognitive ability have been clearly established by various studies [7] [8] [9], the first stage of the project involves testing the hypothesis that, at least for people able to immerse themselves in this virtual world, some of these benefits can be replicated when walking in virtual environments that mimic nature [10]. In this study, we call these real or virtual nature walks, therapeutic ones, referring to their proved or potential benefits. In their meta-analysis (25 studies), Bowler et al. [11] note the following benefits: reduction of anxiety, fatigue and sadness/depression, and the easing of anger. To ensure that the findings of the projected experiments have a degree of internal validity, a controlled virtual environment, specially developed for the study, was first tested with a view to verifying that the perceived atmosphere and the emotions felt by the visitors-both recent and long-term $S L$ residents were invited, and were not necessarily in distress-approximated to what they would experience in reality. The qualitative analysis of the testimonies of these visitors is reported here. After a short description of the virtual environment tested, a succession of verbatim comments reflecting their experience are presented, and are then synthesized by processing on TROPES semantic analysis software. Reading these comments and examining verbal associations should enable us to identify the perceived qualities of the virtual environment visited, the implicit hypothesis being that Natmoud Island reproduces a relaxing natural environment.

\section{Presentation of the Virtual Island of Natmoud ${ }^{1}$}

The island of Natmoud was created in September 2014 for Second Life (SL), a virtual world that has been in existence for more than fifteen years and at any one time still attracts between 25,000 and 60,000 residents from among its 800,000 regular users. Namoud is a "homestead"-type site reserved for universities by the Linden Laboratory at a preferential rate (50\% cheaper) reintroduced by the current CEO EbbeAltberg. The layout of the site was entrusted to PC, a resident of SLfor more than ten years, who invested the US $\$ 300$ allocated for this purpose in varied infrastructure and virtual animals, plants and objects. She has also introduced some of her own virtual acquisitions. The omnipresent sound effects include waves crashing on the rocks as well as birdsong and other natural sounds. If visitors want to hear music, there is a choice of relaxing jazz numbers. They can also engage in activities such as swimming, delta planing, climbing, fitness, dancing, tai chi and meditation. Although a downloadable detailed presentation of a portfolio of images of the original island is available on a Prezi slide show-since its creation, the island has undergone various modifications

${ }^{1}$ Natmoud is the name of the avatar of one of the owners of "La Rose Rouge" in SL (a guinguette at the water's edge), one of the most visited French sites. It was chosen for its originality. 
and additions [12] - the image shown above and the one available online at [13], already give a good idea of the graphic quality and the realism of the landscape. This private island, which is accessible only to residents who are on the guest list, is used for many activities related to graduate studies-virtual meetings are much appreciated during snow storms-or research on virtual reality [14], with meeting places for individual interviews [15] and focus groups [16]. For educational and research activities, it admits Science Circle members [17] upon request, for whom three field visits have been organized. The island is also periodically accessible for a few hours to members of the organization Virtual Ability [18]. On the first visit, the gateway to the island is communicated by a specific landmark for teleportation. The fixed location of this arrival point allows the visitor's avatar to be identified and a file to be sent to him/her containing the reference points for teleportation to various places of interest on the island.

\section{Testimonials from Aconvenience Sample of Visitors}

A convenience sample of residents with varying degrees of experience with one or other of the various interfaces giving access to $S L$ (Linden Lab, Firestorm [19], etc.) were invited to stay on the island of Natmoud and were asked to comment on their visit(s) in writing, either in the form of notes sent within $S L$ to Twilight Rhode, the author's avatar, or by email to his email address. By early June 2018, 85 visitors had been listed, nine of whom commented on their experience following their stay (s). The selection of verbatim comments that follows is intended to verify that the atmosphere experienced during the immersion matches what we wanted to provide by way of support for the subjects of the research project. To preserve the flavor of the comments, they are transcribed entirely in the words and language used by the resident (English or French). The anonymity of the avatars themselves is ensured by using initials, even though, in all cases, the participants consented to the reproduction of the emotions they expressed. Naturally, the ethical rules of research apply also with regard to virtual worlds [20]. A short presentation of the avatar of the originator of the comment precedes what he/she says, so as to put his/her expertise into perspective.

GP is one of the first residents of $S L$. He created a business from his virtual objects that allowed him to live comfortably in real life up until the peak of the metaverse in 2009. Some of his creations are found on the island, but were only incorporated after his visit in the company of a paraplegic friend. At that time, he was managing a magnificent virtual site that attracted a lot of traffic. His comment therefore is that of an expert. "Friday September 26, 2014 [14:15] GP: I have one friend that was a snow mobile accident, I've been bringing her in to $S L$ with screen sharing on skype. I'm her mouse and keyboard (8) maybe I'll bring her by your project tonight she's usually on 5 - 6 hours from now b ... hey, I spelled her name right lol ok, I better get back to work but I'll try to bring her over to the PAUL ${ }^{2}$ island tonight or over the weekend ツ Comments received

${ }^{2}$ GP here uses PAUL (Projet Aînés Université Laval), the acronym temporarily used for the study, in place of Natmoud. 
on October 2: fabulas, you did such a wonderful job on that island:)"

$\mathrm{ON}$ is an artist who has lived in $S L$ for more than ten years. She owns several very beautifully arranged sites there, and has created a variety of decorative objects that she has been trading for some time. She spent many hours on the island prior to making very detailed comments, from which some extracts follow. "arrival ... to be greeted by rabbits, hopping around ... it just raises a chuckle within me ... it is automatically a happy feeling ... a surprise ... and I say ... what delight will follow upon this encounter ...?"/" the villa ... the approach is beautiful ... it is elegant and dignified ... has such excellent design that I feel that I am approaching a place where I shall feel unencumbered by the rest of life ... and can expect courtesy and an escape from "weight" ... that I can escape to books and dignity ... being allowed here ... I feel "accepted" and "worthy" of what is beautiful and clean ... entering the villa ... indeed ... that is the feeling» " the aquarium creates the kind of peace tha" trl aquariums do ... the mesmerizing peacefulness that soothes one so subtly ..."/"... the scenery is so expansive ... never-ending, in fact ... yet the rocks and trees, the greens, the ivy of the gazebo fluttering around the columns ... embrace me ... I can see forever ... or I can curl up in a secure contentment ... like turning the pages of a book of poems ... knowing where small scraps of paper mark the favorites ... this spot is immense ... this spot is cozy ... the reindeer is magnificent as he moves his head abruptly ... as though listening ... smiles ... neither of us is alone here ... the birches on the edge of the cliff ... inspire me ... but to what?"/"the other thing is that ... camped out ... one could shiver at night ... at the seagull who levitates outside the window ... the magic of his feat, mixed with the calls of the other birds (and ... is that a whale calling? ...) could make one wonder if they were nervous about this extraordinary bird ... and whether I should be too ... well ... due to time constraints, I had to choose between the kayak and swimming ... so chose to swim ... even in my good dress (lord have mercy) shoes and all ... I was amazed that I could swim up and down the coast for some ways ... but then I turned back, passed the small building ... and swam into the weeds ... where, lo and behold ... I began to swim up a stream!!!! ... under the bridge I went ... into a waterfall and out again ... and then, beyond ... there is a path that crosses that bridge and offers two directions for explorations ... this was tempting ... more to explore!!!! but time is short so I continue upstream with a promise to return to this path ... and the kayak ..." /" and the beauty of the light reflecting on the surface of the water ... reflections of the landscape ... and that marvelous loon near the wooden footbridge ... oh he is magnificent ... I thought that ... and then he dove!! he dove!! yesssssss ... I had to linger there with him ... what is beauty ... if not that moment? under the bridge ... civilization ... and yet ... on the left bank, two birches peek over a large rock ... and a blanket of purple flowers rest in their shade ... I feel the breath that moves the leaves, the clouds ... a bird calls ... I am content ... right here ... right now ... and I smile ... there is a light ahead ... so I swim to it in the little time that is left ... it is an opening to 
the ocean ... all space opens up ... the sky ... the water ..."/"Submerged Sphere the music is the first thing that I noticed ... there was a clear quality to the selections and instruments that first played ... a bit like the squeal of a finger rubbing the rim of a crystal goblet ... it went well with the invisibility of glass and water ... the gliding or darting of creatures visible around the sphere ... no strings attached ... nor rails to follow ... just freedom and clarity ... the music was well chosen for this environment ... smiles so then, I watched the school of fish ... dancing ... and felt a delight ... other fish hung about... singles and a few with "friends" ... exquisitely created ... convincing in their movements and choice of place from which they kept the same tabs on me that I was keeping on them ... and then, I discovered the shell ... larger than a Rhode Island quahog ... opening and closing ... bereft of the birthing Venus and her accompanying zephyrs ... holding, instead, a huge pearl, (fair trade, or not ... it just depends upon your temperament ...) the subdued light and colors ... I can see dancing in this environment although my real inclination is to lie back, staring upward and outward ... neither asleep nor engaged with anything out of sight ... succumb to listlessness ... feel no more stirring than what the silent, circling fish stir up ... with the one exception of enjoying the burst of bubbles that blast downward each time that orca leaps out of the water ... he is sort of like the moment one is half awake at night ... just for that small moment ... before breathing one's way back to the dream ..."

$\mathrm{NH}$ (female) is a scientist who has been a resident of $S L$ for nine years and plays a vary active part in it. “(Saved Tue Oct 28 15:33:54 2014) Good afternoon Twilight:) this morning we visited your sim and it is truly gorgeous. Peaceful, familiar ... exactly like Pathfinder describes VR should be:)"

DR, NH's assistant, left $S L$ after four years for personal reasons. (Saved Sun Oct 26 06:10:50 2014) Hello Twilight, your sim is amazing!!! It would be wonderful if SC could make a field trip next year to your place. Love it!”

With five years of active presence in $S L$, where she has owned and still owns coastal sites in its virtual seas, LD has become an instructor at an $S L$ sailing school and frequently organizes regattas. She visited the island with her $S L$ partner. "Hi Twi, As you requested here are my impressions. As I have been psychologically distressed more than once, I can respond from that POV. The bunnies at the landing zone are so cute and welcoming - they definitely bring a smile and calming effect. The ocean sounds are also quite nice. We are riding Pat's bicycles which is a nice relaxing activity. The scenery is lovely and calming as are the ocean sounds and seagulls. The bridge and viewpoint at $(200,225)$ are lovely (would I be tempted to jump if depressed?). The trail is very easy to follow with the bicycle. Not the case everywhere that I've biked:-)) The giant conifers and steep slopes remind me of the coast of Washington state. Very lovely and well done! I hope I am not rewarded with any seagull poop:-/ The music near the home where Arabella sleeps and your Looney is moored is very nice and calming. The little hidden boathouse with the exerciser and kayak giver is charming, 
cozy and fun. Why is it so hidden? Maybe a signpost is needed on the bike path? Love the sleeping bags-maybe we'll spend the night here sometime: -) It's a lovely, peaceful meditative spot at $(21,64)$. If we needed to meditate this would be a great spot! We like the pavilion at $(32,240)$. Nice place for a group session. Also, the campfire circle is a nice idea, but could it have a real working fire? My first impression at the end of the trail leading to $(69,244)$ was "where is the 'Lover's Leap' sign?" $=\wedge_{-} \wedge=$ I hope that these impressions are helpful Twi. Please feel free to reply with any questions you might have."

JK has lived in $S L$ for five years and likes to explore the metaverse. This is what she says about her visit. "I find a feeling of peace and tranquility descends as one enters the island. The flora and fauna create a calming influence and one feels that all's well with the world. It is very pleasant to use the various forms of transport to get around the island ... the bicycle for the roads and the horse for the more rugged terrain. It is a pleasure to traverse the coast road and see the waves splashing over the rocks ... washing away the cobwebs of RL. The submerged sphere a place of contemplation and wonder at the killer whale and giant clam, and also dance if one is so inclined. The sailboats are a joy to visit and feeding the fish is fun and sitting on the terrace of Alexander pavilion is restful sipping something long and cool with the world set to midnight ... watching the lights of the stars dance on the ocean. Hang gliding was fun and exhilarating ... smiles. and of course dancing anywhere with a attentive partner is always a joy. All in all I believe Natmoud to be an excellent sim."

The preceding testimonials come from experienced residents. Here are some impressions of "newborns" (less than two months in $S L$ ).

RI (female): “(Saved Sun Oct 26 16:21:21 2014) hey Twilight ... I must say the island is beautiful!! I enjoyed my experience in the island. The panoramic view of the island is spectacular. Initially, I tried to run and cover the grounds of the huge island but that was tiresome to be honest. So the island gave me this file wherein we can use a bicycle and a Scooter. That made life in that island far more interesting and easy. In the Island, the first place that I visited was a beautiful Villa wherein I enjoyed thoroughly. In the route towards this house a beautiful peacock greeted me. After entering the house, I explored every room of the house, which was beautifully ornamented, by variety of artifacts. While I stayed in that house I tried my hand in playing the piano, which I am pretty sure any music lover would definitely enjoy. As for me I have never in my real life had ever tried to play a piano so I was trilled by the experience. One can also try their hands in cooking as all the gadgets and the appliances were easily available, one just have to click on to the menu. I enjoyed visiting the next place called Alexandra Pavillon, wherein I sat in the rocking chairs and did lots of things like cross-stitched, read a book, had a cup of tea. It was enjoyable. I had seen a Reindeer in the woods and also some beautiful swans. Occasionally, I also saw some fishes in the water and for once also caught a glimpse of the killer whale. Spotted some Bunnies hopping around and also surprisingly a horse in the woods. All 
the sounds of birds chirping, murmuring and whistling of water gave a sense of wilderness in the Island. And as I am a nature lover that was those were the first thing that I noticed. While exploring the Island, I came across a Mediterranean Home, where in the entrance of the place I enjoyed the Barbecued cooking. They have made all the necessary objects available in order to grill or cook. So, if anyone wants to go and enjoy some barbecue with their friends, it's an absolutely good place. Inside there are proper meals served, so I enjoyed a delicious meal with a glass of champagne. And in the terrace, there are roof loungers, where one can sunbathe and sip one of your favorite soft drinks. There are a wide range of drinks that you can choose from like \& ups, mountain dew ... and many more or one can also enjoy by just having a ice cream. I had a very good learning experience in this island. The work done in this Island is spectacular. One should definitely visit this place."

UM (female): "If I would have to jot down my experience about the Natmoud Island in one sentence, I would say I was in lust with the Island at my very first glance. It immediately made me feel at home with all the vivid colors and the natural surroundings. After landing on the island, the first thing I did was to retrieve the "Welcome Guide", which actually proved to be a valuable asset. It helped me to gain an interesting and memorable journey. I arrived on a bridge among several rabbits. I was immediately inspired to continue exploring the island. In fact, small brown and white rabbits were walking near me and I was accompanied by marvelous classical music playing in the background. I was very happy to explore while listening to the peaceful music. The starting point seemed warm: the sight of the ocean with white cap waves, a wooden brown bridge. I touched a vase as I was told to do so in order to have an access to the guidelines. I retrieved the bicycle and off I went exploring a new destination. The adventure was enjoyable on the bicycle. It was an exciting experience as I could move faster and appreciate a lot of sceneries in a short period. The first path I chose led me to a beautiful whistling waterfall not far from a splendid massive house surrounded by a blue-violet landscape. A peacock greeted me at the main entrance. I tried to touch it for it to reveal its amazing feathers but unfortunately it didn't response to my touch. ... While I was returning, I saw a dolphin/shark and swans in the water next to a boat. I continued my walk and I heard several animal sounds coming from the forest. It made me feel close to my offline native land. In fact, I heard different sounds that I have heard many times in my childhood years such as birds, frogs, and possibly howling coyotes. This really made me feel nostalgic. Along the pathway, I spotted another house but this one was significantly smaller and I could hear a nice peaceful wind chime sound. In a nutshell, my experience on the island Natmoudis very positive. The gorgeous scenery, the sounds of nature and the vivid colors truly impressed me. The objects received upon arrival was also very much appreciated."

Z (female): "Le centre PAUL procure la paix et donne envie d'être en compagnie. J'aurai aimé être dedans avec mes amis, pour pouvoir partager ce moment, ça aurait été très amusant, surtout la table à manger. En plus il y a de la 
nourriture, en s'assoyant l'avatar mange tout seul. En étant en groupe, toutes les personnes peuvent partager et faire des choses ensemble, sans que cela soit difficile à manipuler. Surfant à partir de ma chambre de résidences, je préférais rester dans la maison le plus longtemps possible, car c'est plus beau que l'endroit où je suis. J'ai des fauteuils, une salle à manger, 2 tables, plusieurs fenêtres, et tout est à moi: c'est parfaitement relaxant. Il y a plusieurs activités autour du centre qui sont amusantes et agréables: le camp de feu est une très bonne idée, je n'ai jamais eu l'occasion de le faire, mais j'ai bien aimé le trouve, la vue de la mer est originale en matinée comme en soirée, surtout avec les étoiles, c'est tellement romantique, le barbecue rajoute aussi une bonne ambiance, le puits d'eau est extraordinaire, le sentiment entre la modernité et l'aspect traditionnel, projette vers une sensation d'indépendance, de reconnaissance du soi, la douche est formidable, l'avatar se lave ses cheveux tout seul, j'ai aimé l'exploration. J'ai pu explorer plusieurs formes de détente: m'asseoir sur les roches et regarder la mer, m'appuyer sur les arbres ou par terre. C'est un parfait endroit de détente, mais encore mieux en groupe. Dans la maison d'Alexandra, il y a une cheminée, avec $\mathrm{du}$ feu, tout comme on le souhaite pendant les saisons froides. Les décorations de noël sont très jolies, mais j'aurai aimé voir des lumières dessus, c'est plus réjouissant. La chambre à coucher est superbe, mais dommage que nous nous puissions se coucher sur le lit, mais le cadre d'animation est très beau. Une pause détente sur les chaises dans la maison alexandra devant la mer m'a beaucoup plu, sauf que je préférais avoir une boisson avec moi, un petit détail qui m'intéresse.La vue sous-marine est belle, mais personnellement je n'aime pas être submergée de l'eau et je suis un peu claustrophobe. Enfin, j'ai aimé la ballade sur la trottinette, je n'ai jamais pu le faire en vie réelle, mais je l'ai très bien réussi sur Second Life."

\section{[Preceding comment translated from French]}

"The PAUL center provides peace and makes you want to be with other people. I would have liked to have been there with my friends, to have been able to share this moment, it would have been great fun, especially around the dining table. What's more, there's food, and the avatar sits there eating alone. Being in a group, everyone can share and do things together, without it being hard to manipulate. Surfing from my room at the residence, I wanted to stay in the house as long as possible, because it's nicer than where I am. I have chairs, a dining room, two tables, several windows, and everything is mine: it's perfectly relaxing. There are various activities around the center that are fun and enjoyable. The camp fire is a very good idea, I never had the opportunity to make it, but I liked it. The view of the sea is original in the morning and evening, especially with the stars, it's so romantic. The barbecue also creates a good atmosphere, the water well is extraordinary, the balance between modernity and the traditional aspect, gives you a feeling of independence, of self-recognition. The shower is great, the avatar is washing her hair all alone. I liked exploring, I was able to try out several types of relaxation: sitting on the rocks and looking at the sea, leaning against trees or lying on the ground. It's a perfect place to relax, but even better in a 
group. In Alexandra's house, there's a fireplace, with a fire, just what you want during the cold season. The Christmas decorations are very pretty, but I would have liked to see lights on it, it would be more cheerful. The bedroom is great, but too bad that we cannot sleep on the bed, but the animation is very beautiful. I liked having a relaxing break sitting on the chairs in Alexandra's house by the sea, except that I'd have liked to have had a drink with me, a small detail that matters to me. The underwater view is beautiful, but personally I don't like being submerged and I'm rather claustrophobic. Finally, I liked the ride on the scooter, I could never do that in real life, but I did very well on Second Life."

\section{Analysis by Means of TROPES}

Because the single French text does not lend itself to an analysis of word associations, only the eight English texts were processed using TROPES semantic analysis software [21], to yield a cluster of associations around the word "feeling". At the same we retain all the texts, as presented above (after transformation into plain text for processing purposes). The following spatial representation puts into orbit various concepts surrounding the idea of "feeling".

The spatial view in Figure 1, representing the verbal associations of all the words expressing the visitors' impressions, is not very satisfactory. For these expressions of feelings are nested in spontaneous streams of words. To make more effective use of TROPES, it is recommended that the texts be purified and condensed prior to analyzing them. The following is what might result from such an exercise.

"wonderful job island arrival rabbits happy feeling surprise elegant dignified excellent design beautiful clean peace peacefulness scenery expansive rocks trees greens immense cozy birches seagull magic birds whale kayak swimming waterfall beauty light loon music fish delight dream amazing love it bunnies so cute welcoming bring a smile calming effect ocean sounds nice relaxing activity scenery lovely calming seagulls giant conifers steep slopes coast of Washington state well done charming cozy fun peaceful meditative spot campfire circle feeling of peace and tranquility flora and fauna create a calming influence very pleasant to use the various forms of transport to get around the island bicycle for the roads and the horse for the more rugged terrain a pleasure to traverse the coast road and see the waves splashing over the submerged sphere a place of contemplation wonder at the killer whale and giant clam dance if one is so inclined sailboats are a joy to visit feeding the fish is fun sitting on the terrace of Alexander pavilion is restful sipping something long and cool with the world set to midnight ... watching the lights of the stars dance on the ocean hang gliding was fun and exhilarating excellent sim I must say the island is beautiful I enjoyed my experience in the island panoramic view of the island spectacular a beautiful villa wherein I enjoyed thoroughly a beautiful peacock greeted me beautifully ornamented, by variety of artifacts playing the piano cooking rocking chairs crossstitched, read a book, had a cup of tea enjoyable reindeer in the woods beautiful swans some fishes in the glimpse of the killer whale bunnies hopping around all 
the sounds of birds chirping, murmuring and whistling of water If gave a sense of enjoyed a delicious meal with a glass of champagne roof loungers sunbathe sip one of your favorite soft drinks a very good learning experience work done spectacular one should definitely visit this place immediately made me feel at home with all the vivid colors and the natural surroundings several rabbits immediately inspired to continue exploring small brown and white rabbits were walking near me very happy to explore peacock greeted me several animal sounds coming from the forest different sounds that I have heard many times in my childhood years such as birds, frogs, and possibly howling coyotes gorgeous scenery"

Figure 2 below presents the results of TROPES processing of this condensed text.

The presence of animals clearly becomes a key factor in the emotions felt, as is shown by the verbal associations that precede or follow these various emotions, all of which are positive in the original texts (7 "beautiful", 3 "nice", 3 "calming", 3 "peaceful", 3 "good"). Figure 3 shows the frequencies of the words preceding or following the use of "feelings".

\section{Conclusions}

As we were able to conclude from reading and analyzing the verbatim comments, the atmosphere created on the island of Natmoud corresponds well to

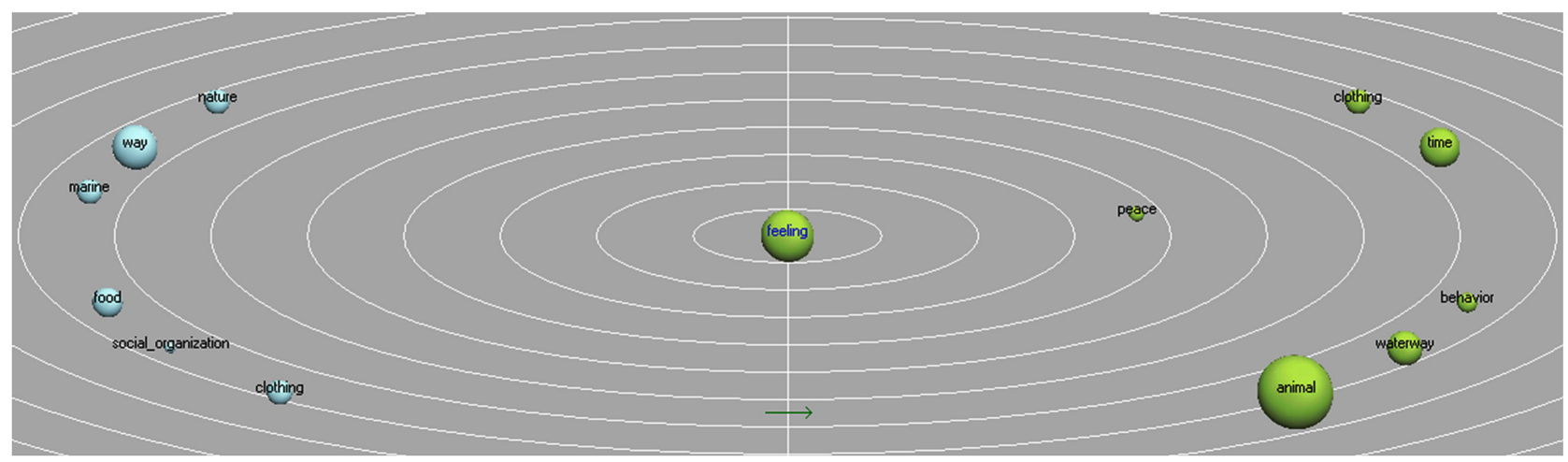

Figure 1. Space of words associated with "feelings" in full texts analysis.

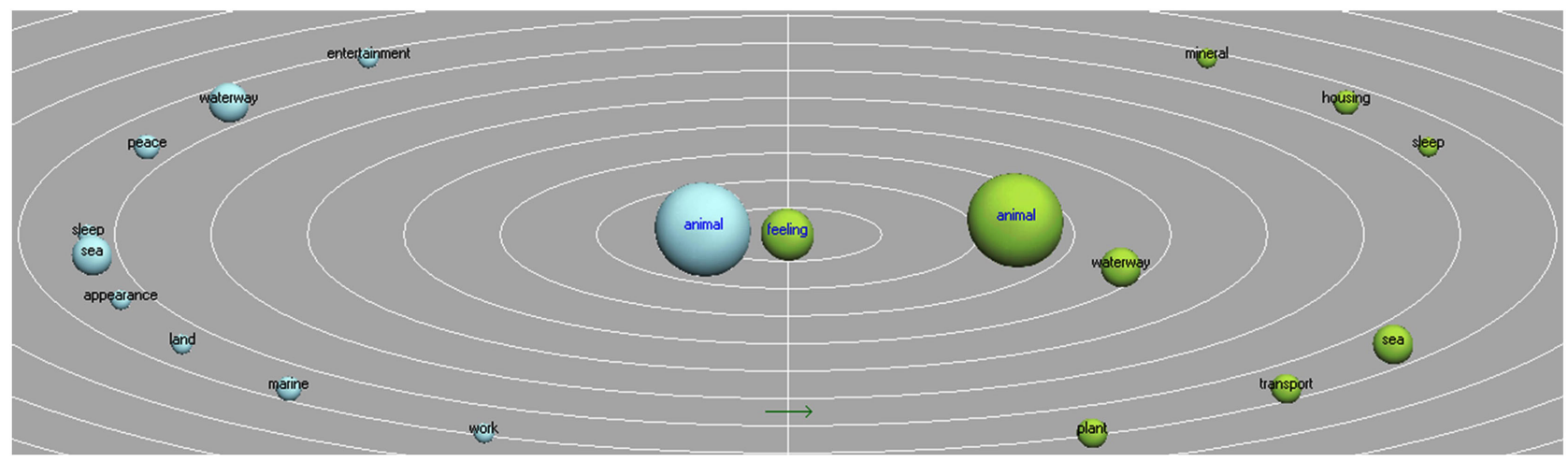

Figure 2. Space of words associated with "feelings" in purified and condensed texts. 


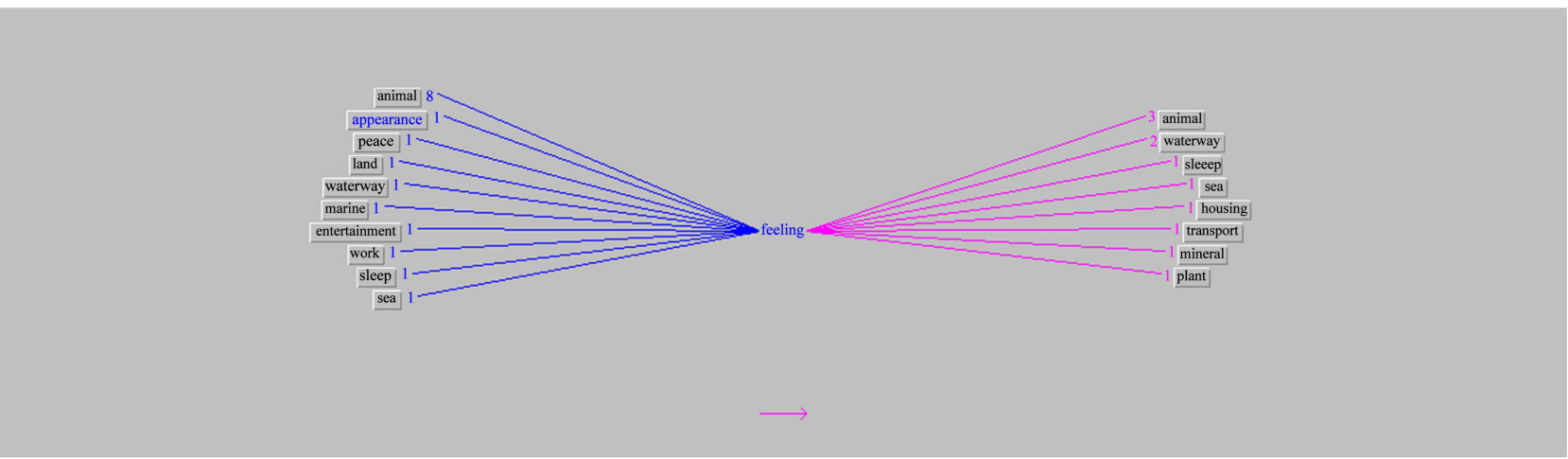

Figure 3. Frequencies of words associated with "feelings" in purified and condensed texts.

what would be appropriate for the therapeutic purposes of the research project. The implicit hypothesis of a soothing and satisfying representation of nature is thus confirmed. We also find that wildlife-which is certainly abundant on the island-seems to be the main feature attracting the attention of walkers. However, since all the comments, with one exception, express the emotions felt by women, one should be cautious about generalizing from them.

The continuation of the original project was temporarily suspended following a number of setbacks. The first was the disappearance of SL Go, which allowed affordable and unlimited access to $S L$ via On Live from tablets (Android and iOS) or from older or less efficient computers for a monthly charge of US \$9.95. Following Sony's purchase of the On Live platform in late April 2015 for its PlayStation, SL Go was withdrawn. Bright Canopy [22] then took over, giving traditional web browsers access to $S L$ for US $\$ 17$ per month for the first 10 hours and three cents a minute thereafter. Not only are the prices very different, but tablets are not served (a beta version is currently being tested). Free access to $S L$ now requires powerful equipment that is not available to everyone. The good news is that the present Linden Lab plan of moving the $S L$ infrastructure to the cloud should improve the affordability. The second setback concerns SL's parallel development of the Sansar virtual world by Linden Lab, which raises an ethical problem, namely immersing vulnerable people in $S L$ with an uncertain future and the risk of them losing their networks of friends and their virtual acquisitions, including their own avatar, within a few years [23]. Today it looks like Linden Lab is committed to keep $S L$ alive investing millions of US \$ last year to upgrade it. The third setback was the departure of one of the project promoters, a researcher from the School of Psychology at Laval University, whose move to the University of Toronto destabilized the balance of the research team. Finally, the US Food and Drug Administration (FDA) has not yet approved saliva stress measures analyzed with the help of a smart phone. Without this approval, these inexpensive and easy tests suggested in 2014 [24] cannot be marketed.

In the meantime, the Island of Natmoud continues to welcome colleagues from the Science Circle [25], postgraduate students for teaching and research 
and occasionally members of Virtual Ability [18]. Current visitors will notice certain changes compared to some of the descriptions provided above. These modifications to the landscape have been made as a result of the general adoption of mesh modeling (more detailed, more complex, more realistic and more creative virtual objects) and in order to take into account the comments made here.

\section{Conflicts of Interest}

The author declares no conflicts of interest regarding the publication of this paper.

\section{References}

[1] http://www.fsa.ulaval.ca/personnel/rigauxbb/docs/SL\%20et\%20les\%20ain\%C3\%A9s .pdf

[2] https://www.lindenlab.com/releases/linden-lab-invites-first-virtual-experience-creat ors-to-project-sansar-testing

[3] https://highfidelity.com/

[4] https://www.wired.com/2017/02/first-they-got-sick-then-they-moved-into-a-virtual -utopia/\#.k0koacrec

[5] https://www.lepoint.fr/sante/des-paraplegiques-retrouvent-une-capacite-de-mouve ment-11-08-2016-2060568_40.php

[6] https://www.youtube.com/watch?v=GQw02-me0W4

[7] Howard, F. (2001) Beyond Toxicity: Human Health and the Natural Environment. American Journal of Preventive Medicine, 20, 234-240.

[8] Terry, H. (2008) Green Space, Psychological Restoration and Health Inequality. The Lancet, 372, 1614-1615.

[9] Berman, M.G., Kross, E., Krpan, K.M., Askren, M.K., Burson, A., Deldin, P.J., Kaplan, S., Skendell, L., Gotlib, I.H. and Jonides, J. (2012) Interacting with Nature Improves Cognition and Affect for Individuals with Depression. Journal of Affective Disorders, 140, 300-305. https://doi.org/10.1016/j.jad.2012.03.012

[10] Depledge, M.H., Stone, R.J. and Bird, W.J. (2011) Can Natural and Virtual Environments Be Used to Promote Improved Human Health and Wellbeing? Environmental Science and Technology, 45, 4660-4665. https://doi.org/10.1021/es103907m

[11] Bowler, D.E., Buyung-Ali, L.M., Knight, T.M. and Pullin, A.S. (2010) A Systematic Review of Evidence for the Added Benefits to Health of Exposure to Natural Environments. BMC Public Health. https://bmcpublichealth.biomedcentral.com/articles/10.1186/1471-2458-10-456

[12] http://www.fsa.ulaval.ca/personnel/rigauxbb/docs/Natmoud\%20Island\%20Promoti on.zip

[13] http://www.fsa.ulaval.ca/personnel/rigauxbb/docs/Fish\%20tank_003.png

[14] Rigaux-Bricmont, B. and El Kamel, L. (2014) La réalité virtuelle: Recherche et application, chapter in "Les réactions affectives du consommateur. Ces raisons du coeur que la raison ignore". In: Poncin, I. and Herrmann, J.-L., Eds., Presses Universitaires de Louvain, 171-186.

[15] El Kamel, L. and Rigaux-Bricmont, B. (2011) Les apports du postmodernisme à l'analyse des univers virtuels comme expérience de consommation. Cas de Second 
Life, Recherche et Applications Marketing, 26, 71-92. https://doi.org/10.1177/076737011102600304

[16] Hervet, G., El Kamel, L. and Rigaux-Bricmont, B. (2010) Entretien de groupe dans Second Life. Recherches Qualitatives, 29, 69-98.

[17] https://secondlife.com/destination/science-circle

[18] http://virtualability.org/

[19] http://www.firestormviewer.org/

[20] Hervet, G., Ellafi, K. and Rigaux-Bricmont, B. (2010) Conducting Research in Virtual Worlds: Ethical and Methodological Reflections. Proceedings of the 4th Annual Conference of the CyberSociety.

[21] http://tropes.fr/

[22] https://brightcanopy.com/

[23] http://www.canarybeck.com/2015/11/20/the-linden-lab-chat-summarised-in-7-min utes/

[24] https://www.news-medical.net/news/20140625/Novel-device-uses-smartphone-tomeasure-cortisol-concentration-in-saliva.aspx

[25] https://www.sciencecircle.org/

\section{Appendix}

To access the island of Natmoud in the virtual world of Second Life, please ask the author or his avatar (twilight.rhode@hotmail.com), stating the name of the avatar who wishes to visit it.

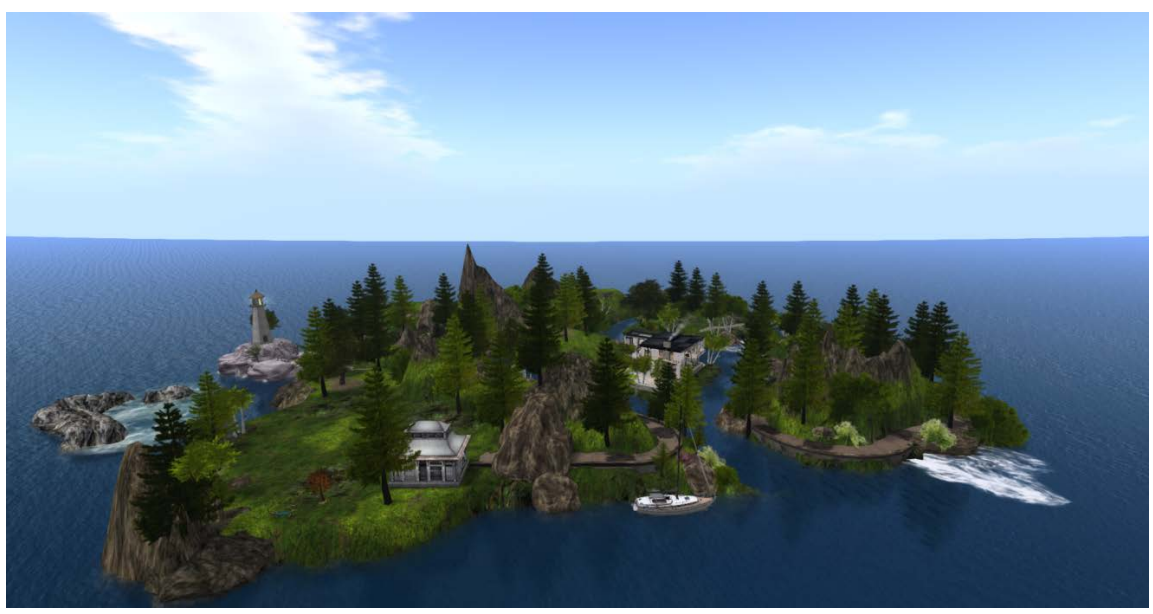

